The Relationship between Employee Attitude Towards Training and Employee Retention in Telecommunication

\author{
Siaw Cheau Jwu ${ }^{1}$, Zaiton Hassan ${ }^{2 *}$, Siti Mariam Abdullah ${ }^{3}$ and Mark Edmund Kasa \\ ${ }^{1-4}$ Universiti Malaysia Sarawak, 94300 Kota Samarahan, Sarawak, Malaysia
}

\begin{abstract}
The objective of this study is to identify the relationship between employee attitude towards training (accessibility of training, social support for training and benefits of training) and employee retention in the telecommunication industry in Kuching. Eighty employees responded to the self-administered questionnaire. Simple random sampling was used to carry out the study. Data was analysed using Pearson Correlation Coefficient and Multiple Regression. Only social support for training had a significant and positive relationship to retention. Thus, it is recommended that managers and supervisors support employees in attending training as well as provide opportunities for employees to apply what they had learned in training as it will influence retention in the organization.
\end{abstract}

Keywords: Retention; accessibility to training; social support for training; benefits of training

Copyright: This is an open access article distributed under the terms of the Creative Commons Attribution-NonCommercialShareAlike 4.0 International (CC BY-NC-SA 4.0) license which permits unrestricted use, distribution, and reproduction in any medium, for non-commercial purposes, provided the original work is properly cited.

\section{BACKGROUND OF STUDY}

Employee retention remains a key (2015) reported the rate of employee retention in Malaysia is still very low; for example, at $40 \%$. Retention keeps on being a key concern for employers in Malaysia due to the decreasing retention scores, more employees are probably leaving the organization

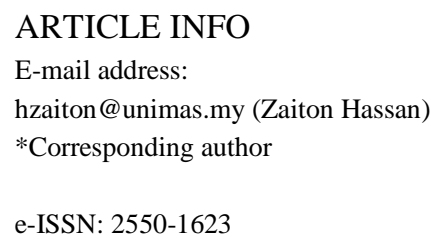

within two years; now $36 \%$ versus $29 \%$ in 2012. Essays (2015) stated that the average voluntary turnover rate for Asia-Pacific countries is $10 \%$ in 2009. Japan reported the lowest rate with only 5\% and India the highest with $13.8 \%$.

The expenses for organizations caused by the employee turnover are increasing, also considering advertising, recruitment, selection, hiring and training. Other than the expenses, there is also a loss of productivity and valuable knowledge. Further explained by Yeong (2005), human resource practices in Malaysia must change and accept the fact that the average turnover for any individual 
nowadays and age is two-and-a-half years, according to one panellist at the Global Business Services Forum 2017. There is significant argument among experts and researchers with regards to the influence that training has on both employee and organizational goals. In order to perform well in such turbulent environment competitively, organizations need to acquire and utilize the human resources adequately such as capital, material, and management information systems. For instance, an organization usually offers their employees with effective training and development programs to enhance employees' skills, which in result, empowers them to react to the rapid changes and growth occurring in the external environment of the organization (Edralin, 2011) and retaining important and potential employees at the same time. These resources can be used in a very effective and efficient way to achieve strategic goals.

Slight drop in revenue growth (2017) reported that Malaysia's telecommunications industry is among the most developed in South-East Asia, boasting a mobile penetration rate of $141.3 \%$ in 2016 and slightly lower than around $149.8 \%$ in Singapore. Ramlan, Yusoff \& Pazim (2013) explained that due to the competition pressure and inefficient use of resources, there are only few firms providing cellular phone service to stay in business, which included Celcom, Maxis, and Digi. Furthermore, The Statistics Portal (2018) shows that there were 21.54 million internet users accessing the internet in Malaysia. This figure is projected to grow to 23.41 million in year 2022. Whereby, the number of smartphone users in Malaysia is estimated to be 19.9 million in 2017.
In addition, telecommunication industry can be recognized as an industry that offers sales marketing and quality products and services to create more value to customer. Hence, it is implied that employees are indeed a telecommunication industry's valuable assets in terms of soliciting customers and presentation of the company's reputation. Efforts are allocated in shaping and retaining this human capital but they do not increase the employee retention. Due to the loss of knowledge and technical skills, it impacts on the organization's productivity, profitability and quality. For this purpose, attracting and retaining the potential employees is on the main tasks of human resource department.

Hence, this study is a timely attempt to study the employees' view on training as a means to improve employee retention in the context of telecommunication industry, one of the significant contributors to the nation's economy.

\section{PROBLEM STATEMENT}

The reasons why telecommunication industry is taken into consideration for this study is that there are very few known studies done in Kuching. This industry is expanding rapidly throughout the recent years as customer's demands and expectations are getting higher. Telecommunication is an industry that deliver services and information most of the time, where it must be professional and well-prepared so that the employees are able to entertain or reach the customers professionally with no doubt. Hence, training is one of the ways for the employees to be professional with extra skill, knowledge and ability in the work- 
place. At the same time, it is essential for the employer to retain the potential and talented employees in the organization by providing them with training and development programs as an investment in order to keep them.

Past studies were limited and focused towards examining the impact of training on both turnover intention and organizational commitment and far fewer studies have investigated those employees who remain in the organization after they have been given training (Newman, Thanacoody, \& Hui, 2011; Jehanzeb, Rasheed \& Rasheed, 2013). Several studies related to the effect of training on employees were conducted in the hotel industry to study whether the employee is going to leave or stay at the same company after they have been given training programs (Alhassan, 2012; Mapelu \& Jumah, 2013). There are also a number of researchers who are more concerned about the relationship between training and organizational commitment as they believed that training has a great impact specifically on organizational commitment (Bartlett, 2001; Bashir \& Choi, 2015; Ismail, 2016; Dias \& Silva, 2016) and job performance (Nassazi, 2013 \& Angela, 2014) after the employees had received the training provided.

Furthermore, the impact of training on employee retention has not been widely researched in Malaysian context as the studies are mostly derived from South Asia and East Asia (Anis, Rehman, Nasir \& Safwan, 2011; Sinha \& Sinha, 2012; \& Chen, 2014). Hence, this research tries to bridge the gap to determine whether training is a significant variable in influencing intention to stay among employees in the telecommunication industry in Kuching, Sarawak. Past research had been conducted in other industries such as hospitality industry (Alhassan, 2012; Mapelu et al., 2013), heavy engineering industry (Sinha et al., 2012), green industry (Bitsch \& Hogberg, 2004), academic sector (Salau, Falola \& Akinbode, 2014; Terera \& Ngirande, 2014; Bashir \& Choi, 2015), and employment agency (Beth, Hamman, Piszczek \& Ruhm, 2015). Thus, this study aims to identify relationship between accessibility of training, social support for training, benefits of training and retention in telecommunication industry in Kuching.

\section{LITERATURE REVIEW}

Irshad (2011) described the support from family members and flex time culture as a significant factor towards employee retention. Compensation, reward and recognition play an important role in employee's motivation which leads to employee's retention in the organization. Hence, training and development were found as motivating factors which lead to employee retention in the organization. Support and motivation are the factors among training to retain the employee in a long run. In addition, it was found in the study that recognition plays an important role for the employees as it enables them to listen that their work is being recognized and appreciated (Das \& Baruah, 2013). Therefore, it gives the employees an impression that their employers value them in the organization and this is the reason why the employees would decide to remain in the organization.

Past researches show that trends redefining current retention strategies that go beyond the salary and benefits package and com- 
pensation (Feldman, 2000) and embracing employee motivation (Thomas, 2000), as one of the key factors to oblige the diversity and long stay of the workforce in the organization. Employee retention factors consolidating the necessities and desires of employees at any age enhance levels of individual job satisfaction, loyalty, and commitment (Bommer Authority, 2009). Employees would remain in the organization due to several factors such as employee recognition, flexibility and training as top priorities for prolonging individual employment. However, Walker (2001) argued that setting up a supportive learning and working climate is essential for employee retention.

\section{Employee Retention}

Retention means keeping the potential employees in the organization and to appreciate their contributions towards the organization with a sense of pride and value. Sinha et al. (2012; p.146) defined retention as "a complex concept and there is no single recipe for keeping employees with a company." From the employee's perspective, employee retention refers to the satisfaction of the employees where they are content with their jobs and they are more devoted to perform well and anticipate to enhance their organizational clients' satisfaction (Denton as cited in Sinha et al., 2012). Retaining potential and talented employees is critical to the telecommunication industry as they need to keep the good employees in the organization in order to stay competitive in the market.

There are different factors which affects employee retention but the most common one is organizational commitment as the employee values the sense of belonging within it, agree with its objectives, and are most probably to remain in the same organization (Curtis \& Wright, 2001). Several researchers pointed out that human resource management practices in compensation and benefits, job security, training and development, organizational support, work environment and organization justice are able to reduce the absenteeism rate, enhance employee retention and better quality work (Alnaqbi, 2011; Haimi, Ahmad, Abdullah Bandar, Abdullah, Sumilan \& Shminan, 2016; and Nabi, Syduzzaman \& Munir, 2016).

One of the mechanisms of employee retention is the use of training programs for the existing employees (Mulder, 2001). Arthur as cited in Mapelu et al. (2013) also agreed that the importance of ensuring employee retention following training may lie in the strategic approach used. Therefore, it can be concluded that one way to retain employee is through training.

\section{Accessibility of Training}

Accessibility of training also known as availability of training where the employees feel that they are capable to access and grab every opportunity to participate in training programs which are offered by their organization. It can also be set through the view of employees with respect to the likelihood to participate or not in the training programs offered by organization. The perception of accessibility of training can be a type of new opportunity to enhance knowledge, skills and abilities which has a very significant impact on organizational commitment (Dias et al., 2016). 
A few researches suggest that employees with positive attitudes and perceptions towards availability of training will be more committed to the organization (Bartlett, 2001). It was also mentioned that availability of training programs are significant features of improving job satisfaction and performance, and decreasing turnover intentions among employees (Jehanzeb et al., 2013). In fact, Logan mentioned that many companies have found out that one of the variables that greatly helps to retain employees is the opportunity to learn and try new things through participating in training (as cited in Sinha et al., 2012).

\section{Social Support for Training}

Support for training can be vertical through the chain of command, or level by colleagues in supporting and motivation to implement better approaches for solving problems in the organization (Dias et al., 2016). Social support refers to support and encouragement from people around which enables the employee to receive positive vibes and influence them in order to perform better. It has vital implications for the proper functioning of the organizations. According to Eisenberger, Stinglhamber, Vandenberghe, Sucharski \& Rhoades (2002), they proposed four main factors of social support for training: colleagues, manager or supervisor, family, and friends. The perception of this support may also have a significant commitment as facilitator for a positive attitude with respect to employees in their work, through participation in training programs (Madera, Seteele \& Beier, 2011). The social support that they received from them is able to influence their attitudes which keeps them motivated to participate more in training activities.

From past decades, scholars have constantly assured that social support is an important source for encouraging the emotional, physical and overall prosperity of the employees (La Rocco et al. as cited in Jehanzeb, 2013). Furthermore, past research stated that social support increases job satisfaction and commitment, and hence increases retention rate (Allen \& Meyer, 1990). This clearly shows that employees feel more associated with the organization with the level of support that they receive from colleagues, managers or supervisors in order to participate in training activities (Bulut \& Culha, 2010). Many reviews have affirmed that support in the workplace has significant implications for the smooth functioning of the organization on a global level, and this support depends on a very close and restricted core, which includes their colleagues and direct supervisors or managers (Newman et al., 2011).

\section{Benefits of training}

Bartlett (2001) distinguished benefits of training into three categories, which are personal benefits, career benefits and jobrelated benefits. According to Mathew \& Zacharias (n.d.), personal benefits refer to employees believing that participation in training programs enable them to organize, enhance their job performance and make progress towards their personal development or self-improvement. Career benefits result from participation in training programs that prompts distinguishing career objectives, achieving career goals and creating chance to pursue new career paths. Job- 
related benefits lead to better relationship amongst colleagues and managers, and provide a fundamental break from the job.

There are several studies conducted demonstrate that there are benefits of training, for instance, it increased performance, and variables with directly related which are innovation and tacit skills, technical skills and selfmanagement skills), and indirectly related (empowerment, communication and planning) (Aguinis \& Kraiger, 2009). Riaz \& Idrees (2013) mentioned that there is significant relationship between employee belief about training benefits and the impact on organizational commitment. The results uncovered that the employees who are having positive attitude towards training as they perceive that they will get distinctive benefits from training and who expect that they will get benefits by participating in training activities, they are probably going to be more dedicated than the individuals who perceive training as a leisure activity.

\section{Herzberg two-factor theory}

The theory underpinning this study is Herzberg two-factor theory. Frederick Herzberg, a psychologist, proposed a twodimensional view of factors that will influence individual's attitudes towards work which are hygiene and motivator factors. $\mathrm{He}$ believes that if the needs of the employees are satisfied and motivated, the employee will stay in their workplace as long as it could be. According to Herzberg, Mausner $\&$ Snyderman (1959), the factors of hygiene are interpersonal relations, supervision, company policy or administrations, salary and working conditions. These factors refer to physiological needs which the employees wanted and expected to be fulfilled. As indicated by the theory, the absence of hygiene factors can lead to job dissatisfaction and increased turnover, but the presence of motivators factors often lead to high retention rate (Coetzee \& Schreuder, 2013).

In contrast, there are factors that are able to improve a person's job or influence an individual to remain in the same organization, which are motivation factors. Those factors are strong determiners of job satisfaction which are achievement, recognition, work itself, responsibility and advancement. Training can be considered as part of motivation factor. These are the factors that make an individual happy with their work. The only differences from motivators are the fact that they are not related to the content of the work but to the context of the job (Armstrong \& Taylor, 2014).

The presence of hygiene factors and the absence of motivators cause employees turnover intention (Maliku, 2014). It is important that in order to retain potential employees, organizations should always find ways of motivating employees to stay with the organization. Retaining people is a longterm relationship between employees and the organization.

\section{METHOD}

Population are all employees in three major telecommunication companies in Kuching. Minimum sample size was 73 respondents identified using formula by Godden (2004). Simple random sampling was used to carry out the study. About 120 questionnaires were distributed through human resource 
manager and 80 questionnaires were collected, resulting in $66.0 \%$ response rate.

\section{Instrument}

The instrument used in this study is closeended questionnaire. It consists of 3 sections which are demographic factor, employee attitude towards training and employee retention. Employee attitude towards training was viewed as the independent variables and was divided into three sub-variables, which are accessibility of training, social support for training and benefits of training. Accessibility of training and benefits of training measured using Newman et al. (2011) consist of 5 items and 8 items respectively. Higher score indicates better access to training in organization and higher scores indicated high benefits of training received by employees. The alpha coefficient for the scale of accessibility of training and benefits of training was 0.903 and 0.859 accordingly. Social support for training was measured by 7 items taken from Maliku (2014) and Newman et al. (2011). Higher score indicates high support received from supervisors and colleagues. The alpha coefficient for the scale of social support for training was 0.896 . To measure employee retention, the researcher used 10 items taken from Newman et al. (2014), Kyndt, Dochy, Michielsen, \& Moeyaert (2009), Byrne (2010), Ng, Lam, Kumar, Ramendran \& Kadiresan (2012). Items included "I see my future within this company" and "I never think of quitting my job." Higher score indicated higher willingness to stay in the organization. The alpha coefficient for the scale of employee retention was 0.941 . The questionnaire was measured using 5-Likert Scale ranging from 1 to 5 , whereas 1 is strongly disagree, 2 is disagree, 3 is neutral, 4 is agree and 5 is strongly agree.

\section{FINDINGS AND DISCUSSION}

Table 1 shows the Pearson Correlation test to determine the relationship between accessibility of training and intention to stay. The results show that $\mathrm{r}=.071$ and $\mathrm{p}=.533$ where the p-value, .533; indicated that there is no significant relationship between accessibility of training and employee retention.

Present study shows distinct results which are similar to Jiang and Klein which expressed that accessibility of training does not enhance employee retention because employees regard them as hygiene factors

Table 1: Mean, Standard Deviation and Pearson Correlation Test between training related variables and retention $(\mathrm{N}=80)$

\begin{tabular}{lccccc}
\hline Section & Mean & SD & Level & $\mathrm{r}$ & $\mathrm{p}$ \\
\hline Accessibility for Training & 4.14 & .78 & High & .071 & .533 \\
Social Support for Training & 3.79 & .85 & Moderate & .247 & .027 \\
Benefits of Training & 4.12 & .66 & High & .073 & .518 \\
Retention & 3.81 & .93 & Moderate & - & - \\
\hline
\end{tabular}


which are necessary to be available (as cited in Terera \& Ngirande, 2014). From the findings, it can be concluded that most of the employees received low training opportunities to expertise in their field career as they seldom undertake general training programs and seminars outside of the organization.

In western context, Shelton (2001) found some of the respondents stated that they had declined the accessibility of training. Besides that, Mueteswa \& Ortlepp (2011) in their study in South Africa for managementlevel employees had found that the lack of effective training opportunities also contradicted in current study as it has a significant impact on managerial-level employees' intention to leave the organization.

Furthermore, the results show that $r=.247$ and $\mathrm{p}=.027$, indicated that there is a moderate relationship between social support for training and intention to stay. Present finding is supported by Eisenberger et al. (2002) as they found superior support absolutely influences employee retention. The relationship between superior or manager and employees play an important role in employees' intention to stay. In the context of East Africa, Greenhaus (as cited in Maliku, 2014) that employees see in regards to organization are strongly concerned with the relationship with superior. If superior always support, open communication and have strong relationship with employees, the turnover intention are likely less and they are more engaged with organization and will never look for any other new employment opportunity rather than remain in the same organization and vice versa (Eketu \& Edeh, 2015). This is due to the employees are able to receive open, honest and constructive feedback on their performance from their superior. By doing this, they are able to come up with new ideas after attending the training program whereby they are provided with clear job objectives and instructions. This situation can be related with Herzberg Two-Factor Theory where the Herzberg's motivation factor (recognition) is often said to lead to high rate of retention (Coetzee et al., 2013). Furthermore, Isimoya \& Bakarey (n.d.) affirmed that employees are more likely to place higher value on training programs that are highly valued by their managers and supervisors. This clearly shows that if the superior recognized them, they feel that they are being valued. Thus, they are satisfied with their employment as they received recognition and their responsibility to contribute to the achievement of work objectives (Aguenza \& Som, 2012).

Silbert (2005) argued that employees respond to support and encouragement regardless of the environment is profession or personal (as cited in Maliku, 2014). Superior can provide valuable or significant feedback to employees and make them feel valued by the organization so that they will not have the intention to leave. The feedback from superior causes employees to feel more responsible, confident and empowered (Bratton \& Gold, 2003). Hence, sooner or later they will feel a lot of loyalty and have strong sense of belonging to the organization.

Table 1 shows no significant relationship between benefits of training and intention to stay. Present findings is supported by Tiwari (2015) where the researcher found that ambitious employee start seeking for other job opportunities due to unclear career path 
within in the organization which cause them to leave the organization as they feel that they did not get any benefits from training. The employee did not receive a better idea of the career path that they wanted to pursue and also lack of opportunities to pursue different career path. Hence, it courses employees to have difficulties in enhancing their career development in the organization in long period of time and intention to turnover is their only choice they could make. In addition, if they are lacking skills and knowledge, they will not get promotion from the top management. Since they got little room for promotion, they start to think that they do not have the sense of belongingness in the organization anymore because they are not being valued by the organization, and hence, they intend to leave the organization in the end.

Multiple regression analysis was used to test if the employee attitude towards training significantly predicted intention to stay. Table 2.0 shows the results of the regression indicated the two predictors, explained $27.8 \%$ of the variance $(\mathrm{R} 2=.072, \mathrm{~F}(1,76)$ $=1.977, \mathrm{p}=125)$. It was found that social support for training significantly predicted intention to stay $(\beta=25, \mathrm{p}<.05)$. Thus, it

Table 2: Model Summary Table (Multiple Regressions)

Model Summary

\begin{tabular}{ccccc}
\hline Model & $\mathrm{R}$ & R Square & Adjusted R Square & Std. Error of the Estimate \\
\hline 1 & $.269^{\mathrm{a}}$ & .072 & .036 & .91948 \\
\hline
\end{tabular}

a. Predictors: (Constant), Accessibility, Social_Support, Benefits

ANOVA $^{\mathrm{a}}$

\begin{tabular}{clccccc}
\hline & Model & Sum of Squares & df & Mean Square & F & Sig. \\
\hline \multirow{2}{*}{1} & Regression & 5.015 & 1 & 1.672 & 1.977 & $.125^{\text {b }}$ \\
& Residual & 64.254 & 76 & .845 & & \\
& Total & 69.269 & 79 & & & \\
\hline
\end{tabular}

a. Dependent Variable: Retention

b. Predictors: (Constant), Accessibility, Social_Support, Benefits

Coefficients $^{\text {a }}$

\begin{tabular}{|c|c|c|c|c|c|c|}
\hline \multirow[b]{2}{*}{ Model } & & \multicolumn{2}{|c|}{ Unstandardized Coefficients } & \multirow{2}{*}{$\begin{array}{c}\text { Standardized } \\
\text { Coefficients }\end{array}$} & \multirow[b]{2}{*}{$\mathrm{t}$} & \multirow[b]{2}{*}{ Sig. } \\
\hline & & $\mathrm{B}$ & Std. Error & & & \\
\hline \multirow{7}{*}{1} & (Constant) & 2.066 & 0.909 & & 2.273 & 0.026 \\
\hline & & & & 0.086 & & \\
\hline & Accessibility & 0.103 & 0.136 & & 0.756 & 0.452 \\
\hline & & & & 0.255 & & \\
\hline & Social_Support & 0.278 & 0.121 & & 2.289 & 0.025 \\
\hline & & & & 0.047 & & \\
\hline & Benefits & 0.066 & 0.16 & & 0.41 & 0.683 \\
\hline
\end{tabular}

a. Dependent Variable: Retention 
can be concluded that social support for training is the most dominant factor of intention to stay.

\section{Implications of Study}

This research helps the organization to understand the influence of training towards employee retention which is social support. Thus, the managers can ensure the employee retention by providing support for training. Training is a huge investment for the organization as they foster employee loyalty and reduces turnover intention. Hence, managers or supervisors should always encourage the employees to come up with new ideas which are beneficial to the organization so that all the difficulties can be solved effectively and efficiently. The superior should give clear job objectives and instruction to the employees. This enables the employees to carry out every task with minimum mistakes. Thus, they are able to produce quality work and increase productivity in order to achieve the goals of the organization. When the employees have the sense of accomplishment, they intended to stay longer in the same organization as they are able to develop career over a long period of time.

\section{CONCLUSION}

The study demonstrated that there is a significant relationship between social support for training and employee retention in telecommunication industry in Kuching. Thus, it is imperative for managers to encourage employees to attend training as well as providing opportunity to apply what they have learned in training. The support not only increase competency of the employees but it will assist in retaining employees in the organization.

\section{REFERENCES}

Aguenza, B. B., \& Som, A. P. M. (2012). Motivational Factors of Employee Retention and Engagement in Organizations. International Journal of Advances in Management and Economics, 1(6), 88-95.

Aguinis, H. \& Kraiger, K. (2009). Benefits of training and development for individuals and teams, organizations, and society. Annual Review of Psychology, 60, 451-474.

Alhassan, J. U. (2011). The relationship between employee perceptions of training, organizational commitment and their impact on turnover intentions: A survey of selected SMMEs in the Cape Metropole area. (Unpublished master's thesis). University of Technology, Cape Peninsula, South Africa.

Allen, N. J., \& Meyer, J. P. (1990). The measurement and antecedents of affective, continuance and normative commitment to the organization. Journal of Occupational Psychology, 63(1), 1-18.

Alnaqbi, W. (2011). The relationship between human resource practices and employee retention in public organizations: An exploratory study conducted in the Unitd Arab Emirates. (Unpublished doctoral dissertation). Edith Cowan University, Australia. Retrieved from http://ro.ecu.edu.au/theses/424/ 
Angela, G. (2014). Effects of training on employee performance: A case study of United Nations support office for the African union mission in Somalia. (Unpublished master's thesis). United States International University, Nairobi, Kenya.

Anis, A., Rehman, I. U., Nasir, A., \& Safwan, N. (2011). Employee retention relationship to training and development: a compensation perspective. African Journal of Business Management, 5(7), 2679-2685. Retrieved from

http://www.academicjournals.org/jour nal/AJBM/articleabstract/ED1BF8F29150

Armstrong, M., \& Taylor, S. (2014). Armstrong's handbook of human resource management practice. $13^{\text {th }}$ Edition. UK: Ashford Colour Press Ltd.

Bartlett, K. R. (2001). The relationship between training and organizational commitment: a study in the health care field. Human Resource Development Quarteyly, 12(4), 335-353.

Bashir, N., \& Choi, S. L. (2015). The relationship between training and organizational commitment among academicians in Malaysia. Journal of Management Development, 34(10), 1227 1245.

Beth, P., Hamman, M. K., Piszczek, M. M., Ruhm, C. J. (2015). The relationship between establishment training and the retention of older workers: evidence from Germany. National Bureau of Economic Research. Retrieved from http://www.nber.org/papers/w21746.p df

Bitsch, V., \& Hogberg, M. (2004). Employee retention: components of job satisfaction of green industry employees. Selected paper prepared for presentation at the American Agricultural Economics Association Annual Meeting, Denver, Colorado. Retrieved from

https://ageconsearch.umn.edu/bitstrea m/20281/1/sp04bi01.pdf

Boomer Authority. (2009). Competitive Strategies for a World Class Workforce. Retrieved from http://boomerauthority.ning.com

Bratton, J., \& Gold, J. (2003). Human Resource Management, Theory and Practice. New York: Palgrave Macmillan.

Bulut, C., \& Culha, O. (2010). The effects of organizational training on organizational commitment. International Journal of Training and Development, 15(1), 309-322.

Byrne, D. (2010). An exploration of the relationship between induction and employee commitment. (Unpublished degree's thesis). National College of Ireland, Dublin.

Chen, M. (2014). The effect of training on employee retention. International Conference on Global Economy, Commerce and Service Science (pp. 356 359). Fuzhou, China: Atlantis Press.

Coetzee, M., \& Schreuder, D. (2013). Personnel Psychology: An Applied Per- 
Siaw Cheau Jwu et al.

spective. South Africa: Oxford University Press.

Curtis, S., \& Wright, D. (2001). Retaining employees - the fast track to commitment. Management Research News, 24(8), 59-64.

Das, B. L., \& Baruah, M. (2013). Employee retention: a review of literature. Journal of Business and Management, 14(2), 8-16.

Dias, A., \& Silva, R. (2016). Organizational training and organizational commitment: a literature review and conceptual framework. International Journal of Innovative Science, Engineering \& Technology, 3(1), 387-399.

Edralin, M. D. (2011). Training and Development Practices of Large Philippines Companies. Asia Pacific Business Review, 17(2), 225-239.

Eisenberger, R., Stinglhamber, F., Vandenberghe, C., Sucharski, I. L. \& Rhoades, L. (2002). Perceived supervisor support: Contributions to perceived organizational support and employee retention. Journal of Applied Psychology, 87, 565-573.

Eketu, C. A., \& Edeh, F. O. (2015). Social intelligence and employee intention to stay. International Journal of Novel Research in Marketing Management and Economics, 2(1), 27-34.

Employee retention remains a key challenge in Malaysia. (2015). Retrieved from https://www.towerswatson.com/en/ Press/2015/01/Employee-RetentionRemains-A- Key-Challenge-inMalaysia
Essays, UK. (2013). Employee turnover and retention in Malaysia Management Essay. Retrieved from https://www.ukessays.com/essays/ma nagement/employee-turnover-andretention-in-malaysia-managementessay.php?cref $=1$

Feldman, D. (2000). The Dilbert syndrome: How employee cynicism about ineffective management is changing the nature of careers in organizations. American Behavioral Scientist, 43, 1286-1301.

Godden, B. (2004). Sample size formulas. Journal of Statistics, 3, 66.

Haimi, N. F., Ahmad, R., Abdullah Bandar, N. F., Abdullah, S. M., Sumilan, H., \& Shminan, A. S. (2016). The relationship between non-financial compensation factors with employees retention in a selected hotel industry. Journal of Cognitive Sciences andHuman Development. 2(1), 49-60.

Herzberg, F., Mausner, B., \& Snyderman, B. B. (1959). The Motivation to Work. 2nd Edition. New York: John Wiley $\&$ Sons.

Irshad, M. (2011). Factors affecting employee retention: Evidence from literature review. Journal of Social Sciences. 4(1), 84-102.

Isimoya, A. O., \& Bakarey, B. E. (n. d.). Employee's perception of training and development opportunities and employee's intention to quit. (Unpublished master's thesis). Lagos State University, Nigeria.

Ismail, H. N. (2015). Training and organizational commitment: exploring the 
Siaw Cheau Jwu et al.

moderating role of goal orientation in the Lebanese context. Journal of $\mathrm{Hu}$ man Resource Development International, 19(2), 152-177.

Jahanzeb, K., Rasheed, A., \& Rasheed, M. F. (2013). Organizational commitment and turnover intentions: impact of employee's training in private sector of Saudi Arabia. International Journal of Business and Management, 8(8), 79-90.

Kyndt, E., Dochy, F., Michielsen, M., \& Moeyaert, B. (2009). Employee retention: organizational and personal perspective, 2, 195. Retrieved from https://doi.org/10.1007/s12186-0099024-7

Madera, J. M., Steele, S. T. \& Beier, M. (2011). The temporal effect of training utility perceptions on adopting a trained method: The role of perceived organizational support. Human Resource Development Quarterly, 22(1), 69-86.

Maliku, M. K. (2014). The perceived relationship between employee retention and organizational performance at national oil corporation of Kenya. (Unpublished master's thesis). University of Nairobi, Nairobi, Kenya.

Mapelu, I. C., \& Jumah, L. (2013). Effect of training and development on employee turnover in selected medium sized hotels in Kisumu city, Kenya. Journal of Tourism, Hospitality and Sports, 1 , 43-48.

Mathew, G. A., \& Zacharias, S. (n. d.). Employee benefits from training and organizational commitment - a review.
Mahatma Gandhi University, Tamil Nadu, India.

Mulder, M. (2001). Customer satisfaction with training programs. Journal of European Industrial Training, 25(6), 321-331.

Muetswa, R., \& Ortlepp, K. (2011). Contributing factors to potential turnover in a sample of South African management-level employees. Acta Commercii, 13-29.

Nabi, M. N., Syduzzaman, M., Munir, M. S. (2016). The impact of human resource management practices on job performances: A case study of Dhaka Bank Private Limited, Bangladesh. Human Resouce Management Research, 6(2), 45-54.

Nassazi, A. (2013). Effects of training on employee performance: evidence from Uganda. (Unpublished master's thesis). University of Applied Sciences, Uganda, East Africa.

Newman, A., Thanacoody, R., \& Hui, W. (2011). The impact of employee perceptions of training on organizational commitment and turnover intentions: a study of multinationals in the Chinese service sector. International Journal of Human Resource Management, 22(8), 1765-1787.

Ng, E. C. H., Lam, Z. H., Kumar, R., Ramendran, C., \& Kadiresan, V. (2012). An effectiveness of human resource management practices on employee retention in institute of higher learning: A regression analysis. International Journal of Business Research and Management, 3(2), 60-79. 
Siaw Cheau Jwu et al.

Ramlan, W. K., Yusoff, R., \& Pazim, K. H. (2013). Where do telecommunication industry in Malaysia stand? An evidence from SWOT analysis. Proceedings of the $6^{\text {th }}$ International Conference of the Asian Academy of Applied Business (AAAB), Sabah, Malaysia. Retrieved from http://www.ums.edu.my/fpep/files/EC O06_2013.pdf

Riaz, A., \& Idrees, R. N. (2013). Employees belief regarding training benefits and organizational commitment: A case in banking sector of Pakistan. Journal of Scientific Research, 16(3), 310-318.

Salau, O. P., Falola, H. O., \& Akinbode, O. (2014). Induction and staff attitude towards retention and organizational effectiveness. Journal of Business and Management, 16(4), 47-52.

Sinha, C., \& Sinha, R. (2012). Factors affecting employee retention: a comparative analysis of two organizations from heavy engineering industry. $E u$ ropean Journal of Business and Management. 4(3), 145-162.

Slight drop in revenue growth seen for telcos. (2017, July 17). The Star Online. Retrieved from https://www.thestar.com.my/business/ business-news/2017/07/17/slightdrop-in-revenue-growth-seen-fortelcos/
Terera, S. R., \& Ngirande, H. (2014). The impact of training on employee job satisfaction and retention among administrative staff members: a case of a selected tertiary institution. Journal of Social Science, 29(1), 43-50.

The Statistics Portal. (2018). Number of smartphone users in Malaysia from 2015 to 2022. Retrieved from https://www.statista.com/statistics/4 94587/smartphone-users-in malaysia/

Thomas, Kenneth W. (2000). Intrinsic motivation at work-Building energy andcommitment. San Francisco: BerrettKoehler.

Tiwari, Ishani. (2015). An analysis of the factors affecting employee retention and turnover in the Irish hospitality industry. (Unpublished master's thesis). National College of Ireland, Ireland.

Walker, J.W. (2001), "Zero defections?", Human Resource Planning, 24(1), 68.

Yeong, E. (2017, July 20). Average job turnover for a person is two-and-ahalf-years. The Sun Daily. Retrieved from http://www.thesundaily.my/news/201 7/07/20/average-job turnoverperson-2\%C2\%BD-years 